\title{
Faktor-Faktor Yang Mempengaruhi Pelaksanaan Supervisi Akademik Sekolah Dasar Di Kecamatan Nirunmas Kabupaten Maluku Tenggara Barat
}

\author{
Yoseph Batkunde ${ }^{1 *}$, Zakarias Bacori $^{2}$ \\ Program Studi Pendidikan Matematika, Sekolah Tinggi Keguruan Dan Ilmu Pendidikan Saumlaki, Indonesia \\ ${ }^{1}$ ybatkunde@gmail.com; ${ }^{2}$ batsorychaken@gmail.com;
}

\begin{abstract}
Abstrak
Pengawasan akademik merupakan upaya membantu guru dalam mengembangkan kemampuannya dalam mencapai tujuan pembelajaran. Pelaksanaan pengawasan akademik oleh pengawas sekolah diharapkan dapat memotivasi guru dalam menjalankan tugasnya dan dapat meningkatkan kualitas pendidikan di Kecamatan Nirunmas. Penelitian ini bertujuan untuk mengetahui: Faktor-faktor yang mempengaruhi kebijakan pengawasan dalam mengawasi akademik di sekolah dasar di Kecamatan Nirunmas Kabupaten MTB. Penelitian ini menggunakan penelitian deskriptif menggunakan metode kualitatif. Penelitian dilakukan di Kecamatan Nirunmas dengan waktu penelitian selama 8 bulan. Mata pelajaran penelitian tersebut adalah pengawas SD, guru SD dan Kepala SD se-Kecamatan Nirunmas. Data dikumpulkan melalui wawancara, observasi, dan dokumentasi. Verifikasi validitas data menggunakan teknik triangulasi. Analisis data menggunakan analisis model interaktif. Hasil penelitian menunjukkan bahwa: Faktor-faktor yang mempengaruhi kebijakan pengawasan dalam melakukan pengawasan akademik meliputi: komunikasi, sumber daya manusia, sumber daya anggaran, sumber daya peralatan, disposisi atau sikap, letak geografis, dan kondisi jalan yang rusak parah. Berdasarkan permasalahan yang ditemukan, disarankan kepada pengawas sekolah agar dapat melaksanakan tugas dan tanggung jawabnya dengan baik, serta pemerintah daerah Kabupaten MTB dalam rangka membantu pengawas sekolah di Kecamatan Nirunmas dalam mengatasi faktor-faktor yang mempengaruhi pelaksanaan pengawasan akademik.
\end{abstract}

Kata kunci: Supervisi, Akademik

\section{Factors Influencing the Implementation of Primary School Academic Supervision in Nirunmas Subdistrict, West Southeast Maluku Regency}

\begin{abstract}
Academic supervision is an effort to assist teachers in developing their ability to achieve learning objectives. The implementation of academic supervision by school supervisors is expected to motivate teachers in performing their duties and can improve the quality of education in Nirunmas sub-district. This research aim was to know:Factors which influencing supervisor policy in supervising academic at elementary school in Nirunmas sub-district MTB regency. This research used descriptive research used qualitative method. The research was conducted in Nirunmas sub-district with research time for 8 months. The subjects of the study were elementary school supervisor, elementary school teachers and head of elementary school in Nirunmas sub-district. Data were collected by interview, observation and documentation. Verification of data validity used triangulation technique. Data analysis used interactive model analysis. The result of the research shown that:Factors that influencing supervisory policy in conducting academic supervision included: communication, human resources, budget resources, equipment resources, disposition or attitude, geographical location, and the condition of severely damaged road.
\end{abstract}

Keywords: Supervision, Academic. 


\section{PENDAHULUAN}

Pendidikan merupakan investasi yang paling utama bagi setiap bangsa, dan juga telah menjadi kebutuhan untuk memajukan peradaban manusia, sehingga pendidikan memegang peran yang sangat penting dalam meningkatkan sumber daya manusia.

Menurut Rizqa, 2013 dalam (Batkunde 2019: 1) Pendidikan merupakan investasi yang paling utama bagi setiap bangsa, dan juga telah menjadi kebutuhan untuk memajukan peradaban manusia. Pendidikan dikatakan bermutu apabila proses pembelajaran berlangsung secara efektif, serta siswa memperoleh pengalaman yang bermakna bagi dirinya, masyarakat maupun pembangunan bangsa.

Salah satu fungsi utama pendidikan adalah pengembangan kesadaran nasional, karena kesadaran nasional merupakan sumber daya mental dalam proses pembangunan kepribadian yang tersusun dari karakteristik perwatakan yang tumbuh dan melembaga dalam proses pengalaman sepanjang kehidupan bangsa. Dengan demikian, kepribadian nasional serta identitas suatu bangsa bertumpu pada pengalaman kolektif bangsa, yang bersifat historis.

Salah satu tujuan Negara Indonesia adalah mencerdaskan kehidupan bangsa. Untuk mewujudkan tujuan ini, maka Undang-Undang Dasar 1945 pasal 31 ayat (1) ditegaskan bahwa "Tiap-tiap warga Negara berhak mendapat pengajaran". Kemudian dalam ayat (2) ditegaskan pula bahwa "Pemerintah mengusahakan dan menyelenggarakan suatu sistem pendidikan nasional yang diatur dengan Undang-Undang.

Ketentuan dasar untuk mencerdaskan kehidupan bangsa ini kemudian ditindaklanjuti dengan Undang-Undang Nomor 20 Tahun 2003 tentang Sistem Pendidikan Nasional, yang mengamanatkan bahwa pendidikan nasional berfungsi mengembangkan kemampuan dan membentuk watak serta peradaban bangsa yang bermartabat dalam rangkamencerdaskan kehidupan bangsa.

Kualitas pendidikan di sekolah bukan hanya ditentukan oleh usaha siswa secara individual tetapi juga ditentukan oleh kinerja guru dan kepala sekolah yang ada di sekolah tersebut. Sehingga Profesionalisme dan akuntabilitas guru merupakan suatu keharusan (sine quonom) dalam meningkatkan mutu kelulusan. Guru yang profesional memerlukan sistem pembinaan kerja yang baik, tersistem dan berkelanjutan. Agar guru dan kepala sekolah mempunyai kinerja yang baik, maka diperlukan suatu pengawasan.

Menurut Sahertian, (2000:19) pengertian supervisi yaitu usaha memberi pelayanan kepada guru-guru baik secara individual maupun secara kelompok dalam usaha memperbaiki pengajaran. Supervisi juga merupakan pembinaan yang diberikan kepada seluruh staf sekolah agar mereka dapat meningkatkan kemampuan untuk mengembangkan situasi belajar mengajar yang lebih baik. Menurut Muslim (2010:41) supervisi akademik adalahserangkaian usaha pemberian bantuan kepada guru dalam bentuk layanan profesional yang diberikan oleh supervisor (kepala sekolah, penilik sekolah dan pembina lainnya) guna meningkatkan mutuproses dan hasil belajar mengajar.

Menurut Permen PAN \& RB No. 21 Tahun 2010 Pasal 5, tugas pokok pengawas sekolah adalah melaksanakan tugas pengawasan akademik dan manajerial pada satuan pendidikan yang meliputi penyusunan program pengawasan, pelaksanaan pembinaan, pemantauan pelaksanaan delapan Standar Nasional Pendidikan, penilaian, pembimbingan, dan pelatihan profesionalisme guru, evaluasi hasil pelaksanaan program pengawasan, dan pelaksanaan tugas kepengawasan di daerah khusus.

Dalam pelaksanaan pengawasan seringkali supervisi mengalami beberapa kendala. Hendiyat dan Wasty (1984:62) mengindikasikan ada tiga hambatan dalam pelaksanaan pengawasan, (1) faktor organisasi pengawas karena kurangnya pengenalan dan kesadaran tentang tanggungjawab pengawas serta kegagalan dalam menetapkan wewenang dan tanggungjawab pengawas, (2) di pihak pengawas, yang kurang dipersiapkan menjadi pengawas, pengalaman belajar yang pernah diperoleh di saat preservice education belum menjadi bekal yang cukup untuk melaksanakan tugas pengawasan. Kurangnya pengetahuan dan ketrampilan pengawas daripada kepala sekolah dan pemimpin-pemimpin pendidikan lainnya, akan menghambat pelaksanaan pengawasan pendidikan, (3) sikap guru-guru terhadappengawas merupakan faktor penting dalam pelaksanaan pengawasan.

Berdasarkan hasil pengamatan peneliti ketika melakukan observasi awal letak geografis dari tiap sekolah, dan belum meratanya jaringan telekomunikasi di semua desa di Kecamatan Nirunmas juga mempengaruhi kinerja pengawas.

Melihat fenomena yang terjadi sebagaimana telah dipaparkan di atas, tentu dapat diprediksi bahwa mutu pendidikan sekolah dasar pada Kecamatan Nirunmas Kabupaten MTB menjadi terabaikan, dengan demikian perlu di cari alternatif/solusi yang baik untuk menyelesaikan fenomena yang terjadi. Sehingga penulis tertarik untuk melakukan 
penelitian dengan judul "Faktor-Faktor Yang MempengaruhiPelaksanaan Supervisi Akademik Sekolah Dasar di Kecamatan Nirunmas Kabupaten Maluku Tenggara Barat"

\section{METODE}

\subsection{Jenis Penelitian}

Berdasarkan jenisnya, penelitianini menggunakan penelitian deskriptifdengan menggunakan metode kualitatif.Artinya data yang dikumpulkan bukan merupakan angkaangka,melainkan data tersebut berasal dari hasil wawancara, catatan lapangan, dokumen pribadi, dan dokumen resmi lainnya.Pada penelitian ini akan mendeskripsikan tentang efektivitas pelaksanaan supervisi akademik SD di Kecamatan Nirunmas Kabupaten MTB.

\subsection{Subjek dan Objek Penelitian}

Yang menjadi subjek penelitian dalam penelitian ini adalah pengawas SD, guru SD, dan Kepala SD yang terdiri dari 1 orang pengawas sekolah binaan yang merupakan pengawas senior yang mewakili pengawas sekolah binaan, 1 orang pengawas umum yang mewakili pengawas umum, 2 orang kepala sekolah yang mewakili SD di Kecamatan Nirunmas Kabupaten MTB dan 4 orang guru kelas yang merupakan guru senior atau memiliki kemampuan yang baik untuk dapat membantu peneliti dalam memberikan informasi, sedangkan yang menjadi objek penelitian dalam penelitian ini adalah 4 Sekolah Dasar di Kecamatan Nirunmas Kabupaten MTB yang terdiri dari 2 SD Swasta dan 2 SD Negeri.

\subsection{Teknik Analisis Data}

Analisis data adalah suatu kegiatan mencari dan menyusun secara sistematis data yang diperoleh dari hasil penelitian terutama dengan menggunakan teknik panduan observasi, wawancara dan dokumen-dokumen lainya, sehingga mudah dipahami dan temuannya dapat disampaikan dan diinformasikan kepada orang lain, faktor-faktor yang mempengaruhi pelaksanaan supervisi akademik. Dengan demikian teknik analisis data yang digunakan dalam penelitian ini adalah mengacu pada konsep Milles \& Huberman, (1992:20) yaitu interaktifmodel yang mengklasifikasikan analisis data dalam empat tahap, yaitu :

\subsection{Pengumpulan Data}

Data yang diperoleh dari hasilwawancara, observasi dan dokumentasi dicatat dalam catatan lapangan yang terdiri dari dua bagian yaitu deskriptif dan reflektif. Catatan deskriptif adalah catatan alami, (catatan tentang apa yang dilihat, didengar, disaksikan dan dialami sendiri oleh peneliti tanpa adanya pendapat dan penafsiran dari peneliti terhadap fenomena yang dialami. Catatan reflektif adalah catatan yang berisi kesan, komentar, pendapat, dan tafsiran peneliti tentang temuan yang dijumpai, dan merupakan bahan rencana pengumpulan data untuk tahap berikutnya.

\subsection{Reduksi Data}

Data yang diperoleh dari lapangan dituangkan dalam laporan berupa :

Catatan lapangan (Hasil wawancara dengan pengawas sekolah, guru dan kepala sekolah).

Administrasi pengawas (Kalender pengawasan, program dan jadwal supervisi, instrumen monitoring, instrumen supervisi akademik, instrumen supervisi administrasi rencana pembelajaran, dan data calistung).

Setelah data terkumpul, selanjutnya di buat reduksi data, guna memilih data yang relevan dan bermakna, memfokuskan data yang mengarah untuk memecahkan masalah, penemuan, pemaknaan atau untuk menjawab pertanyaan penelitian.

\subsection{Penyajian Data}

Data diperoleh dari pelaksanaan supervisi akademik Sekolah Dasar di Kecamatan Nirunmas Kabupaten MTB di buat dalam bentuk deskripsi lewat hasil wawancara dan observasi, kemudian disortir sesuai kelompok dan disusun sesuai katagori jenis agar selaras dengan permasalahan yang dihadapi termasuk kesimpulan yang diperoleh pada waktu reduksi data.

\subsection{Penarikan Kesimpulan}

Dalam rangka memperjelas suatu hasil penelitian ilmiah maka peneliti harus memberikan kesimpulan. Penarikan kesimpulan dilakukan setelah data dikumpulkan maka peneliti menyusun laporan yang menggambarkan seluruh proses penelitian, penyusunan desain penelitian, pengolahan data dan penefsiran data. 


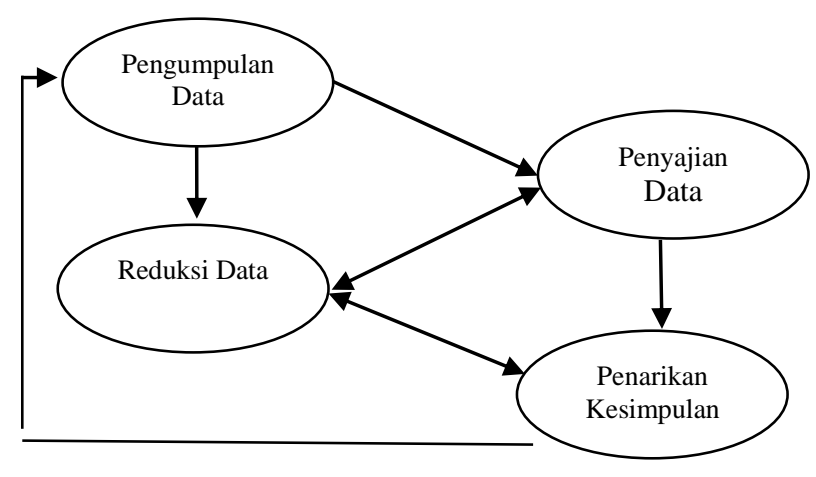

Gambar 4. Komponen-komponen Analisis Data. Model Interaktif

\section{HASIL DAN PEMBAHASAN}

\subsection{Hasil}

\begin{tabular}{|c|c|c|}
\hline Faktor-Faktor & yang & Mempengaruhi \\
\hline Kebijakan & Pengawas & Sekolah \\
\hline
\end{tabular}

\section{a. Comunication/komunikasi}

Berdasarkan hasil wawancara dengan pengawas sekolah (L.B) terkait hubungan komunikasi antara pengawas dengan guru dikatakan bahwa "Komunikasi itu kadangkadang kita melalui hp, misalnya besok mau lakukan supervisi berarti sebentar kita sudah hubungi besok pengawas ke sana walaupun mereka sudah baca program"di tambahkan pulah oleh dirinya bahwa "Hubungan komunikasi antara pengawas dengan guru sangant baik, malah mereka itu ramah-ramah karena kita ajarkan pada mereka sehingga ada guru yang kita dapat dia tidak punya ramah maka kita panggil langsung kita tegur tidak boleh seperti itu karena itu tatakrama sudang mengatur",

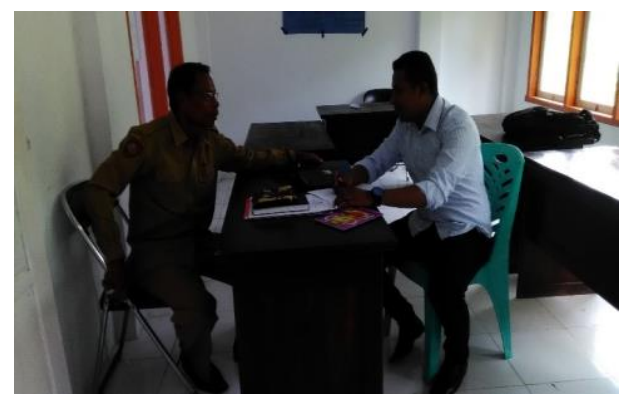

Gambar 1. Hasil Wawancara Dengan Pengawas Sekolah

Dan setelah dilakukan konfirmasi dengan guru SD Kristen Arma (G.B) mengatakan bahwa "Hubungan komunikasi kita dengan pengawas baik"

Hasil penelitian menunjukan bahwa hubungan komunikasi antara pengawas dengan guru adalah berjalan dengan baik sehingga tidak berpengaruh pada implementasi program pengawas di Kecamatan Nirunmas Kabupaten MTB.

\section{b. Resources/sumber daya}

Berdasarkan hasil wawancara dengan pengawas sekolah (L.B) terkait dengan tingkat kecukupan sumber daya manusia dalam rangka melaksanakan kegiatan pengawasan sekolah dikatakan bahwa "Kalau menurut bapak baik sekali, hanya saja kita ini dari segi pengawas tidak punya elektronik sehingga itu yang mempersulit kita dan kita berakses itu kadangkadang dari sisi trasportasi juga"

Keterangan berbeda disampaikan oleh pengawas sekolah binaan (M.S) yang mengatakan bahwa "Cukup, tidak terlalu baik dan tidak terlalu buruk". Sedangkan keterangan berbeda di sampaikan oleh guru SD Kristen Manglusi (Y.E) ketika dilakukan wawancara mengatakan bahwa "Pengawas Sekolah Dasar di Kecamatan Nirunmas ini memiliki SDM yang berbeda, ada yang baik tetapi ada juga yang kurang, karana mereka tidak pernah mengikuti pelatihan.Kecuali pengawas SMP sehingga dalam melaksanakan tugasnya kadang di pengaruhi oleh faktor SDM dari pengawas itu sendiri"

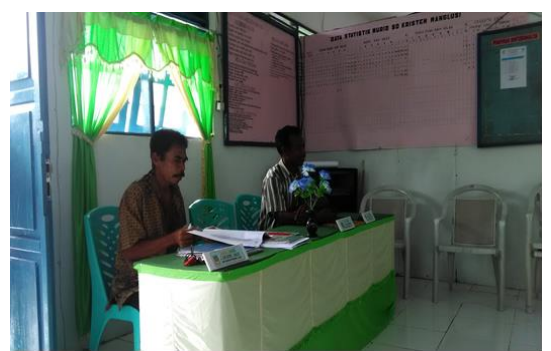

Gambar 2. Wawancara Dengan Guru SD Kristen Manglusi

Hasil penelitian menunjukan bahwa sember daya manusia yang dimiliki oleh pengawas sekolah binaan di Kecamatan Nirunmas sangat berpengaruh terhadap implementasi program yang di buat tersebut.

\section{c. Sumber daya anggaran}

Berdasarkan hasil wawancara dengan pengawas sekolah binaan (M.S) terkait dengan tingkat kecukupan sumber daya anggaran dalam rangka melaksanakan kegiatan pengawasan sekolah dikatakan bahwa "Ya, ini pengawas turun di sekolah setiap minggu itu pribadi yang menanggung jadi tergantung dari pada gaji, kalau gaji di jalan kita turun tapi kalau pertengahan tidak ada gaji lagi kita tidak turun. Sebab mengingat pada transportasi saja, misalnya dari tutukembong ke arma saja Rp 150.000 jadi kalau PP Rp 300.000 untuk sekali 
turun lakukan supervisi. Jadi keungan sangat berpengaruh pada implementasi kebijakan" Ditambahkan oleh dirinya bahwa "Tidak ada sama sekali keungan yang diberikan oleh pemerintah daerah kepada pengawas untuk melakukan supervisi".

Pernyataan tersebut sejalan dengan apa yang dialami oleh peneliti ketika bersama dengan pengawas melakukan monitoring kegiatan awas semester.Dengan demikian dapat disimpulkan bahwa sumber daya anggaran sangat berpengaruh pada implementasi kebijakan pengawas sekolah di Kecamatan Nirunmas Kabupaten MTB.

\section{d. Sumber daya peralatan}

Berdasarkan hasil wawancara dengan pengawas sekolah binaan (M.S) terkait dengan tingkat kecukupan sumber daya peralatan dalam rangka melaksanakan kegiatan pengawasan sekolah dikatakan bahwa "Tidak ada sama sekali”.

Kemudian di tambahkan juga oleh pengawas umum (L.B) bahwa "Sangat berpengaruh, pengawas belum punya sama sekali bahkan tidak pernah diberikan bantuan apapun oleh pemerintah daerah Kabupaten MTB kepada pengawas sekolah di Kecamatan Nirunmas.

Hasil penelitian menunjukan bahwa sumber daya peralatan sangat berpengaruh pada implementasi kebijakan pengawas sekolah di Kecamatan Nirunmas Kabupaten MTB.

\section{e. Sumber daya kewanangan}

Berdasarkan hasil wawancara dengan pengawas sekolah binaan (M.S) terkait dengan tingkat kecukupan sumber daya peralatan dalam rangka melaksanakan kegiatan pengawasan sekolah dikatakan bahwa "Kita selalu menjunjung tinggi sikap saling menghormati dan menghargai jadi setiap kebijakan yang di ambil selalu dilakukan musyawarah sebelum melakukan kebijakan tersebut".

Hasil penelitian menunjukan bahwa sumber daya kewenangan tidak berpengaruh pada implementasi kebijakan pengawas sekolah di Kecamatan Nirunmas Kabupaten MTB.

\section{f. Disposition/disposisi}

Berdasarkan hasil wawancara dengan pengawas sekolah binaan (M.S) terkait dengan tingkat disposisi pengawas sekolah dalam melaksanakan kebijakan pengawas sekolah dikatakan bahwa "Tidak ada, semuanya hanya untuk kepentingan pendidikan semata.Jadi kita punya program disini kita kenasa dan laksanakan sesuai dengan kebutuhan sekolah.Untuk kepentingan lain-lain tidak" .
Kemudian ketika dilakukan konfirmasi dengan guru SD Inpres Manglusi (A.L) dikatakan bahwa "Selama ini belum pernah terjadi hal demikian yang dilakukan oleh pengawas".

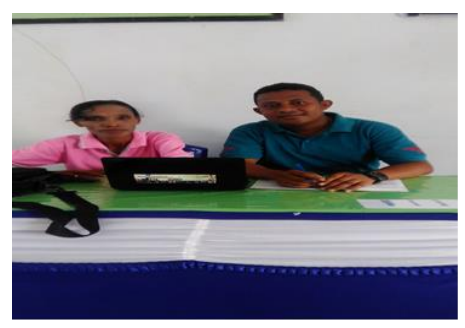

Gambar 3. Wawancara dengan Guru SD Kristen Manglusi

Hasil penelitian menunjukan bahwa tingkat disposisi pengawas sekolah tidak berpengaruh pada implementasi kebijakan pengawas sekolah di Kecamatan Nirunmas Kabupaten MTB.

\subsection{Pembahasan}

Faktor-faktor yang Mempengaruhi Kebijakan Pengawas Sekolah dalam Melakukan Supervisi Akademik

Implementasi merupakan tindakan-tindakan yang dilakukan oleh pemerintah untuk mencapai tujuan yang telah ditetapkan dalam suatu keputusan kebijakan.Akan tetapi pemerintah dalam membuat kebijakan juga harus mengkaji terlebih dahulu apakah kebijakan tersebut dapat memberikan dampak yang buruk atau tidak bagi masyarakat.Hal tersebut bertujuan agar suatu kebijakan tidak bertentangan dengan masyarakat apalagi sampai merugikan masyarakat (Edward III, 1980:1).

Menurut Lester dan Stewart (2000) (Winarno, 2002:101-102) implementasi kebijakan pada prinsipnya merupakan caraagar sebuah kebijakan dapat mencapai tujuannya. Implementasi kebijakan adalah: "Implementasi kebijakan dipandang dalam pengertian luas merupakan alat administrasi hukum dimana berbagai actor, organisasi, prosedur dan teknik yang bekerja bersama-sama untuk menjalankan kebijakan guna meraih dampak atau tujuan yang diinginkan".

Definisi diatas menekankan bahwa implementasi kebijakan merupakan sesuatu yang dilakukan untuk menimbulkan dampak atau akibat dapat berupa Undang-undang, peraturan pemerintah, keputusan peradilan dan kebijakan yang dibuat lembaga-lembaga pemerintah dalam kehidupan bernegara.

Implementasi kebijakan menurut (Nugroho, 2003:158) terdapat dua pilihan untuk mengimplementasikannya dalam bentuk program-program dan melalui formulasi kebijakan derivate atau turunan dari kebijakan tersebut. Oleh karena itu, implementasi 
kebijakan yang telah dijelaskan oleh Nugroho merupakan dua pilihan, dimana yang pertama langsung mengimplementasikan dalam bentuk program dan pilihan kedua melalui formulasi kebijakan.

Sebagai tolok ukur keberhasilan kebijakan pendidikan adalah dapat dilihat pada bagaimana implementasinya.Rumusan kebijakan yang dibuat bukan hanya sekedar berhenti pada tataran rumusan, melainkan harus secara fungsional dilaksanakan. Sebaik apa pun rumusan kebijakan yang dibuat, jika tidak diimplementasikan, tidak akan dapat dirasakan manfaatnya. Sebaliknya sesederhana apa pun rumusan kebijakan, jika sudah diimplementasikan, akan lebih bermanfaat, apa pun hasilnya.

Pada dasarnya implementasi kebijakan pendidikan tidak menjadi monopoli birokrasi pendidikan yang secara hierarkis dilakukan dari paling atas di kementerian pendidikan dan kebudayaan sampai paling bawah yaitu sekolah sebagai ujung tombak pelaksana otonomi pendidikan. Dalam implementasi kebijakan pendidikan baik pemerintah, masyarakat serta sekolah idealnya secara bersama-sama dan saling bahu membahu dalam bekerja dan melaksanakan tugas-tugasnya demi suksesnya implementasi kebijakan pendidikan dimaksud.

Berdasarkan pengertian diatas maka dalam pembahasan terkait faktor-faktor yang mempengaruhi kebijakan pengawas sekolah dalam melakukan supervisi akademik dijabarkan sebagai berikut :

\section{a. Comunication/komunikasi}

Hasil penelitian terkai dengan faktor-faktor yang mempengaruhi kebijakan pengawas dalam melakukan supervisi akademik menunjukan bahwa komunikasi sangatlah penting dalam menentukan keberhasilan pencapaian tujuan dari pelaksanaan. Pelaksanaan yang efektif terjadi apabila para pembuat keputusan sudah mengetahui apa yang akan dikerjakan.Pengetahuan atas apa yang akan dikerjakan dapat berjalan apabila komunikasi berjalan dengan baik, sehingga setiap keputusan danperaturan pelaksanaan harus ditransmisikan (dikomunikasikan) kepada bagian personalia yang tepat.

Keberhasilan suatu implementasi kebijakan Menurut Hogwood dan Gunn (1986)(Wahab, 2005:77) komunikasi memegang peranan penting bagi berlangsungnya koordinasi implementasi kebijakan.Koordinasi bukanlah sekedar menyangkut persoalan mengkomunikasikan informasi ataupun membentuk struktur-struktur administrasi yang cocok, melainkan menyangkut pula persoalan yang lebih mendasar, yaitu praktik pelaksanaan kebijakan.

Menurut Trenholm dan Jensen (Fajar, 2009:31), komunikasi merupakan suatu proses di mana sumber mentransmisikan pesan kepada penerima melalui beragam saluran. Suatu proses yang mentransmisikan pesan kepada penerima pesan melalui berbagai media yang dilakukan oleh komunikator adalah suatutindakan komunikasi. Selanjutnya menurut Weaver (Fajar, 2009:32),komunikasi adalah seluruh prosedur melalui pemikiran seseorang yang dapat mempengaruhi pikiran orang lain.

Effendy (2002:60), menjelaskan bahwa komunikasi merupakan proses penyampaian suatu pesan dalam bentuk lambang bermakna sebagai pikiran dan perasaan berupa ide, informasi, kepercayaan, harapan, himbauan, dan sebagai panduan yang dilakukan oleh seseorang kepada orang lain, baik langsung secara tatap muka maupun tidak langsung melalui media, dengan tujuan mengubah sikap, pandangan atau prilaku.

Secara terminologis, komunikasi berarti proses penyampaian suatu pernyataan oleh seseorang kepada orang lain.Dari pengertian tersebut, jelas bahwa komunikasi melibatkan sejumlah orang dimana seseorang menyatakan sesuatu kepada orang lain. Komunikasi yang dimaksudkan di sini adalahkomunikasi manusia atau dalam bahasa asinghuman communication yang seringpula disebut komunikasi sosial atau socialcommunication. Komunikasi manusia sebagai singkatan dari komunikasiantar manusia dinamakan komunikasi sosial atau komunikasi kemasyarakatan karena hanya pada manusiamanusia yang bermasyarakatkomunikasi dapat terjadi. Masyarakat terbentuk dari paling sedikit dua orang yang saling berhubungan dengan komunikasi sebagai penjalinnya.

Komunikasi dapat dilakukansecara langsung maupun menggunakan media. Contoh komunikasi langsung tanpa media adalah percakapan tata muka, pidato tatap muka dan lain-lain sedangkan contoh komunikasi menggunakan media adalah berbicara melalui telepon, mendengarkan berita lewat radio atau televisi dan lain-lain. Menurut Effendy (2003:8), komunikasi dilakukan dengan tujuan untuk perubahan sikap(attitude change), perubahan pendapat (opinion change),perubahan perilaku(behaviour change)dan perubahan sosial (social change).

Pakar komunikasi Joseph A Devito mengemukakan komunikasi sebagai transaksi. Transaksi yang dimaksudkannya bahwa komunikasi merupakan suatu proses dimana komponen-komponennya saling terkait dan bahwa para komunikatornya beraksi dan bereaksi sebagai suatu kesatuan dan 
keseluruhan. Dalam setiap proses transaksi, setiap elemen berkaitan secara integral dengan elemen lain (Suprapto, 2006:5).

Berdasarkan penjelasan teori diatas maka faktor-faktor yang mempengaruhi komunikasi dalam implementasi kebijakan harus adanya kejelasan petunjuk dalam implementasi kebijakan dan kejelasan, konsistensi dalam menjalankan sebuah kebijakan maka dengan terpenuhinya ketiga faktor pendukung komunikasi maka akan tercapainya sebuah implementasi kebijakan yang baik dan sesuai tujuan yang telah ditetapkan.

Berdasarkan landasan teori di atas, hasil petelitian terkait dengan faktor-faktor yang mempengaruhi pengawas sekolah dalam melakukan supervisi akademik melalui program kerja pengawas dalam hal ini komunikasi menunjukan bahwa hubungan komunikasi yang terjalin antara pengawas dengan tenaga pendidik dan kependidikan maupun kepala UPT-BS berjalan dengan baik.

Menurut hemat peneliti hubungan komunikasi antara elemen-elemen dalam pendidikan berjalan dengan baik namunkomunikasi langsung secara tatap muka seringkali di pengaruhi oleh intensitas bertemu pengawas yang berjalan kurang baik selain itu, komunikasi tidak langsung melalui media juga berjalan dengan kurang baik akibat keterjangkaun signal yang belum merata pada seluruh daerah atau temapt tinggal pengawas sehingga terkadang komunikasi dilakukan melalui pegawai UPT-BS atau masyarakat sehingga penyampaian informasi terkadang tidak secara merata kepada seluruh pengawas sekolah sehingga sering berpengaruh pada implementasi kebijakan yang telah direncanakan.

Berdasarkan hasil penelitian yang telah dipaparkan pada bagian sebelumnya dan pengamatan langsung yang dilakukan peneliti selama berada di lokasi penelitian maka, kesimpulan akhir dari hubungan komunikasi antara pengawas dengan guru adalah berjalan dengan kurang baiksehingga faktor komunikasi berpengaruh terhadap supervisi akademik pengawas di Kecamatan Nirunmas Kabupaten MTB.

\section{b. Resources/sumberdaya}

Menurut George C. Edward III bahwa sumber-sumber yang dapat menentukan keberhasilan pelaksanaan adalah salah satunya sumberdaya yang tersedia, karena menurutGeorge C Edward III sumberdaya merupakan sumber penggerak dan pelaksana. Manusia merupakan sumberdaya yang terpenting dalam menentukan keberhasilan proses pelaksanaan, sedangkan sumberdaya merupakan keberhasilan proses implementasi yang dipengaruhi dengan pemanfaatan sumberdaya manusia, biaya, dan waktu.

Menurut Edward III (Widodo 2010:98) bahwa sumberdaya tersebutmeliputi sumberdaya manusia, sumberdaya anggaran, sumberdaya peralatan dan sumberdaya kewenangan.

\section{c. Sumberdaya manusia}

Sumber Daya Manusia (SDM) merupakan salah satu variabel yang mempengaruhi keberhasilan pelaksanaan kebijakan. Selain itu SDM adalah salah satu faktor yang sangat penting bahkan tidak dapat dilepaskan dari sebuah organisasi.Pada hakekatnya SDM berupa manusia yang dipekerjakan di sebuah organisasi sebagai penggerak, pemikir dan perencana untuk mencapai tujuan organisasi itu.

Menurut Anifral Hendri (2008:3) menyatakan bahwa sumberdaya manusia adalah daya energi yaitu kekuatan yang bersumber pada diri sendiri manusia yang memiliki kompetensi untuk membangun dalam arti positif.

Dengan demikian dalam melakukan pengawasan dalam rangka meningkatkan mutu pendidikan di Kecamatan Nirunmas Kabupaten MTB, sumberdaya pengawas sangatlah penting sebagai penggerak, pemikir dan perencana untuk mencapai visi, misi dan tujuan pengawasan tersebut.

Hasil penelitian menunjukan bahwa pengawas sekolah di Kecamatan Nirunmas Kabupaten MTB memiliki kemampuan SDM yang berbeda-beda dengan kualitas yang berbeda pula yaitu ada yang baik dan ada yang kurang.Hal tersebut disebabkan pengawas SD di Kecamatan Nirunmas Kabupaten MTB tidak pernah mengikuti pelatihan kepengawasan baik di tingkat Kecamatan maupun di tingkat Kabupaten.

Rendahnya SDM pengawas tentunya akan sangat berpengaruh terhadap implementasi kebijakan karena dalam implementasi kebijakan melalui program pengawas dibutuhkan kemampuan yang baik dari pengawas untuk merealisasikannya akar tidak salah sasaran. Rendahnya SDM yang di miliki pengawas sekolah juga di pengaruhi oleh kualifikasi pendidikan yang dimiliki oleh pengawas sekolah, dengan demikian perhatian pemerintah daerah Kabupaten MTB sangatlah dibutuhkan dalam melaksanakan pelatihan pengembangan kompetensi bagi pengawas sekolah di Kecamatan Nirunmas sehingga dapat meningkatkan kualitas sumber daya pengawas untuk lebih baik dan berkualitas lagi.

Dengan demikian dapat disimpulkan bahwa sumber daya manusia yang dimiliki oleh 
pengawas sekolah binaan di Kecamatan Nirunmas sangat berpengaruh terhadap pelaksanaan supervisi akademik.

\section{d. Sumberdaya anggaran}

Sumberdaya anggaran merupakan salah satu faktor terpenting dalam mengimplementasi program kebijakan.Hasil temuan menunjukan bahwa sumberdaya anggaran sangat berpengaruh dalam pelaksanaan supervisi akademik.Hal tersebut disebabkan karena letak geografis dari setiap sekolah di Kacamatan Nirunmas yang terbilang jauh sehingga untuk dapat mencapai sekolah-sekolah harus menggunakan kendaraan bermotor/mobil.Selain itu, Tidak ada sama sekali keungan yang diberikan oleh pemerintah daerah kepada pengawas untuk melakukan supervisi padalah harga trasportasi untuk sekali jalan Rp 150.000 jadi kalau perg pulangi Rp 300.000 untuk sekali turun lakukan supervisi.

Hal tersebut sejalan dengan apa yang dialami oleh peneliti ketika bersama dengan pengawas melakukan monitoring kegiatan awas semester. Edward III (Widodo 2010:101) menyimpulkan bahwa terbatasnyasumber daya anggaran akan mempengaruhi keberhasilan pelaksanaan kebijakan. Disamping program tidakbisa dilaksanakan dengan optimal, keterbatasan anggaran menyebabkan disposisi para pelaku kebijakan rendah.

Dengan demikian dapat disimpulkan bahwa sumberdaya anggaran sangat berpengaruh terhadappelaksanaan supervisi akademik di Kecamatan Nirunmas Kabupaten MTB.

\section{e. Sumberdaya peralatan}

Edward III (Widodo 2010:102) menyatakan bahwa sumberdaya peralatan merupakan sarana yang digunakan untuk operasionalisasi implementasi suatu kebijakan yang meliputi gedung, tanah, dan sarana yang semuanya akan memudahkan dalam memberikan pelayanan dalam implementasi kebijakan.

Hasil penelitian menunjukan bahwa pengawas sekolah di Kecamatan Nirunmas tidak memiliki sumberdaya peralatan apapun dalam pelaksanaan supervisi akademik selain itu pengawas sekolah di Kecamatan Nirunmas tidak pernah diberikan bantuan apapun oleh pemerintah daerah Kabupaten MTB.

Berdasarkan pengamatan langsung oleh peneliti ketika melakukan observasi awal sebelum melakukan penelitian bahwa pengawas sekolah tidak memiliki sumberdaya peralatan apapun yang digunakan untuk operasionalisasi implementasikebijakan pengawas, bahkan dalam ruangan pengawas hanya terdapat enam buah meja dan enam buah kursi tanpa komputer dan peralatan lain apapun yang bisa digunakan untuk membantu pelaksanaan supervisi akademik.

Menurut hemat peneliti seharusnya pengawas sekolah di Kecamatan Nirunmas Kabupaten MTB di berikan sumberdaya peralatan yang memadai oleh pemerintah Kabupaten MTB karena letak geografis antara UPT-BS dan sekolah-sekolah yang cukup jauh, selain itu penyusunan program serta administrasi kepengawasan lainnya membutuhkan sumberdaya peralatan sehingga seluruh aktifitas dan administrasi pengawas dapat berjalan dengan baik demi terwujudnya pendidikan yang baik dan berkualitas di Kecamatan Nirunmas Kabupaten MTB.

Dengan demikian dapat disimpulkan bahwa sumberdaya peralatan sangat berpengaruh terhadap pelaksanaan supervisi akademik di Kecamatan Nirunmas Kabupaten MTB.

\section{f. Sumberdaya kewanangan}

Sumberdaya lain yang cukup penting dalam pelaksanaan supervisi akademikadalah kewenangan. Menurut Edward III (Widodo 2010:103) menyatakan bahwa: Kewenangan (authority) yang cukup untuk membuat keputusan sendiri yang dimiliki oleh suatu lembaga akan mempengaruhi lembaga itu dalam melaksanakan suatu kebijakan. Kewenangan ini menjadi penting ketika mereka dihadapkan suatu masalah dan mengharuskan untuk segera diselesaikan dengan suatu keputusan. Oleh karena itu, EdwardIII (Widodo 2010:103), menyatakan bahwa pelaku utama kebijakan harus diberi wewenang yang cukup untuk membuat keputusan sendiri untuk melaksanakan kebijakan yang menjadi kewenangannya.

Hasil penelitian menunjukan bahwa pengawas sekolah selalu menjunjung tinggi sikap saling menghormati dan menghargai jadi setiap kebijakan yang di ambil selalu dilakukan musyawarah sebelum melakukan kebijakan tersebut, selain itu selalu dilakukan komunikasi yang baik antara pengawas sehingga semua hal yang ingin dilakukan selalu dikomunikasikan terlebih dahulu antar sesama pengawas setelah itu baru dijalankan bersama.

Dengan demikian dapat disimpulkan bahwa sumberdaya kewenangan tidak berpengaruh terhadap pelaksanaan supervisi akademik di Kecamatan Nirunmas Kabupaten MTB.

\section{g. Disposition/disposisi}

Disposisi atau sikap dari pelaksana kebijakan adalah faktor penting ketiga dalam pendekatan mengenai implementasi suatu 
kebijakan. Jika implementasi suatu kebijakan ingin efektif, maka para pelaksana kebijakan tidak hanya harus mengetahui apa yang akan dilakukan tetapi juga harus memiliki kemampuan untuk mekaksanakannya, sehingga dalam praktiknya tidak menjadi bias. Hal-hal penting yang perlu di cermati pada variabel disposisi adalah pengangkatan birokrat dan insentif.

Selain itu jika para pelaksana bersikap baik karena menerima suatu kebijakan maka kemungkinan besar mereka akan melaksanakan secara bersungguh-sungguh seperti tujuan yang diharapakannya. Sebaliknya jika perspektif dan tingkah laku para pelaksana berbeda dengan para pembuat kebijakan maka proses implementasi akan mengalami kesulitan. Karena itu, pengangkatan dan pemilihan personel pelaksana kebijakan haruslah orangorang yang memiliki dedikasipada kebijakan yang telah ditetapkan, lebih khusus lagi pada kepentingan lembaga pendidikan.

Kecakapan saja tidak mencukupi tanpa ketersediaan dan komitmen untuk melaksanakan kebijakan tersebut.Edward III mengatakan bahwa "kecenderungankecenderungan atau disposisi merupakan salah satu faktor yang mempunyai konsekuensi penting bagi implementasi kebijakan yang efektif'.Apabila pelaksana bersikap baik atau adanya dukungan terhadap suatu kebijakan tertentu, kemungkinan besar mereka melaksanakan sebagaimana yang diinginkan oleh pembuat keputusan. Begitu juga berlaku sebaliknya apabila terjadi hal yang berlawanan. Bentuk penolakan menurutnya bermacammacam, seperti yang dikemukakan Edward III tentang "zona ketidakacuhan". Dalam hal ini para pelaksana kebijakan melalui keleluasaanya menghambat implementasi kebijakan dengan cara mengacuhkan, menunda dan lain sebagainya (Winarno 2005:142-143).

Berdasarkan penjelasan diatas bahwa dalam mendukung dispositions dalam kesuksesan implementasi kebijakan harus adanya kesepakatan antara pembuat kebijakan dengan pelaku yang akan menjalankan kebijakan itu sendiridan bagaimana mempengaruhi pelaku kebijakan agar menjalakan sebuah kebijakan tanpa keluar dari tujuan yang telah ditetapkan demi terciptanya pelayanan publik yang baik.

Hasil temuan menunjukan bahwa disposisi atau sikap yang di tunjukan pengawas semuanya hanya untuk pengembangan pendidikan semata dan tidak ada indikasi lain yang mempengaruhi sikap pengawas misalnya, politik, suku, agama, ras dan golongan.Selain itu kebijakan yang dikeluarkan berdasarkan musyawarah untuk mufakat sehingga kebijakan tersebut telah disepakati bersama oleh seluruh pengawas sekolah sebelum mengimplementasi kebijakan tersebut.

Menurut hemat peneliti ketika berada di lokasi penelitian dan melakukan monitoring awal semester justru berbanding terbalik dengan keterangan yang di berikan oleh responden baik guru maupun pengawas sekolah yaitu peneliti menemukan bahwa adanya disposisi atau sikap kurang baik yang ditunjukan oleh beberapa orang pengawas dengan tidak menjalankan program yang telah dijadwalkan tersebut tanpa keterangan yang jelas sehingga hanya sebagian pengawas yang melakukan kegiatan tersebut. Bahkan ada informasi yang disampaikan oleh salah seorang pengawas bahwa kejadian seperti ini sering dilakukan oleh yang bersangkutan dengan berbagai alasan yang tidak jelas, sehingga hal tersebut sangat mempengaruhi kegiatan monitoring awal semester yang dilakukan.

Dengan demikian dapat disimpulkan bahwa disposisi atau sikap pengawas sekolah berpengaruh terhadap pelaksanaan supervisi akademik di Kecamatan Nirunmas Kabupaten MTB.

\section{h. Letak geografis}

Letak geografis dari setiap sekolah maupun tempat tinggal pengawas merupakan salah satu faktor yang mempengaruhi pelaksanaan supervisi akademik. Jarak antara satu sekolah dengan sekolah lain yang cukup jauh menyebabkan terhambatnya pelaksanaan supervisi akademik karena untuk mencapai satu sekolah membutuhkan biaya yang cukup besar.

Dengan demikian letak geografis merupakan salah satu faktor yang mempengaruhi pelaksanaan supervisi akademik pengawas sekolah di Kecamatan Nirunmas Kabupaten MTB.

Berdasarkan keseluruhan pembahasan terkait dengan faktor-faktor yang mempengaruhi implementasi kebijakan pengawas sekolah dalam pelaksanaan supervisi akademik yang telah dikaji di atas makadapat disimpulkanbahwa faktor-faktor yang mempengaruhi implementasi kebijakan pengawas sekolah dalam pelaksanaan supervisi akademik adalah:komunikasi, sumberdaya manusia, sumberdaya anggaran, sumberdaya peralatan, disposisi, dan letak geografis.

\section{KESIMPULAN}

Faktor-faktor yang mempengaruhi kebijakan pengawas dalam melakukan pengawasan antara lain: (a) Komunikasi, (b) sumberdaya manusia, (c) sumberdaya anggaran, 
(d) sumberdaya peralatan, (e) disposisi atau sikap, (f) Letak geografis.

\section{DAFTAR PUSTAKA}

[1] Depdiknas. 2011. Peraturan Menteri Negara Pendayagunaan Aparatur Negara dan Reformasi Birokrasi.Nomor 21, Tahun 2010 tentang Jabatan Fungsional Pengawas Sekolah dan Angka Kreditnya.

[2] Edward III, George C. 1980. Implementing Public Policy. Washington DC : Congressional Quarterly Press.

[3] Effendy, Onong Uchjana. 2002. Hubungan Masyarakat Suatu Studi Komunikologis. Bandung : Remaja Rosdakarya.

[4] Fajar, Marhaeni. 2009. Ilmu Komunikasi : Teori dan Praktik. Yogyakarta : Graha Ilmu.

[5] Joko Widodo. 2010. Analisis Kebijakan Publik, Konsep dan Aplikasi Analisis Kebijakan Publik. Malang: Bayu Media

[6] Muslim, Sri Banun. 2009. Supervisi Pendidikan Meningkatkan Kualitas Profesionalisme Guru. Bandung: Alfabeta

[7] Sahertian, A. P. 2000. Konsep Dasar dan Teknik Supervisi Pendidikan dalam Rangka Mengembangkan Sumber Daya Manusia. Jakarta: Rineka Cipta.

[8] Suprapto, Tommy. 2006. Pengantar Teori Komunikasi, Cetakan Pertama, Yogyakarta: Media Pressindo.

[9] Wahab, Solichin Abdul. 2004. Analisis Kebijakan Dari Formulasi ke Implementasi Kebijakan Negara. Jakarta: PT Bumi Aksara.

[10] Yoseph Batkunde, 2019. Efektivitas Pembelajaran Kimia Menggunakan Metode Inkuiri dan Model Kooperatif Tipe Stad Konsep Larutan Elektrolit dan NonElektrolit Pada Siswa Kelas X SMA Negeri 1 Nirunmas Kabupaten MTB, Vol. 2, ISSN 2626-3363, 2019. 